\title{
Effect of Pitch Ratio and Diagonal Length of Pin Fin of Heat Sink on Convective Heat Transfer for Turbulent Flow Condition
}

\author{
Noora Imad Haseeb Algburi ${ }^{1 *}$, Hayati Kadir Pazarlioglu ${ }^{2}$, Kamil Arslan ${ }^{3}$ \\ 1* Karabuk University, Faculty of Engineering, Departmant of Mechanical Engineering, Karabuk, Turkey, (ORCID: 0000-0001-6503-9051), \\ nura561152@gmail.com \\ ${ }^{2}$ Karabuk University, Faculty of Engineering, Departmant of Mechanical Engineering, Karabuk, Turkey, (ORCID: 0000-0002-9365-9431), \\ hayatikadirpazarlioglu@gmail.com \\ ${ }^{3}$ Karabuk University, Faculty of Engineering, Departmant of Mechanical Engineering, Karabuk, Turkey, (ORCID: 0000-0002-1216-6812), \\ kamilarslan@karabuk.edu.tr
}

(1st International Conference on Applied Engineering and Natural Sciences ICAENS 2021, November 1-3, 2021)

(DOI: 10.31590 /ejosat.1009980)

ATIF/REFERENCE: Algburi, N., I., H., Pazarlioglu, H.K., \& Arslan, K. (2021). Effect of Pitch Ratio and Diagonal Length of Pin Fin of Heat Sink on Convective Heat Transfer for Turbulent Flow Condition. European Journal of Science and Technology, (28), 643-652.

\begin{abstract}
In this study, the impact of pitch ratio and diagonal length of pin fin on the heat sink has been numerically investigated to determine the thermo-hydraulic performance of heat sink under turbulent flow regime. Usage of pin fin on the heat sink has been preferred due to less pressure drop in comparison with general fin type. While the pitch ratio has been changed $0.75 \leq P / e \leq 1.1$, the length of edge of fin has been changed $3 \leq L_{e f} \leq 6$ as geometric parameters. The working range of the study has been considered as turbulent flow regime ( 2658 $\leq R e \leq 7138$ ). The computational study has been carried out on ANSYS Fluent $2020 R 2$ using SST $k$ - $\omega$ with low-Re correction model to calculate RANS equations. The factors, which define thermo-hydraulic performance of the study, such as average Nusselt number, average Darcy friction factor, and thermal resistance has been elucidated in detail. Also, to detect flow characteristics comprehensively, the contours have been created for vorticity, temperature, and velocity streamline. As a results of overall assessment of this study, it is concluded that the maximum convective heat transfer performance has been obtained using Case 12 by $52 \%$ compared with the Case 1 at $R e=7138$.
\end{abstract}

Keywords: Heat sink, Hexagonal pin fin, Convective heat transfer, CFD.

\section{Türbülanslı Akış Durumunda Isı Kuyusunun İğne Kanatçı̆̆ının Adım Oranının ve Köşegen Uzunluğunun Konvektif Isı Transferine Etkisi}

\begin{abstract}
$\ddot{O} \mathbf{z}$
Bu çalışmada, türbülanslı akış rejimi altında 1sı kuyusunun termo-hidrolik performansını belirlemek için 1sı kuyusu üzerindeki iğne kanatçığın köşegen uzunluğu ve adım oranının etkisi sayısal olarak araştırılmıştır. Genel kanatçık tiplerine kıyasla daha az basınç düşümüne sebep olduğu için iğne kanatçık kullanımı tercih edilmiştir. Geometrik paramtere olarak, adım oranı $0.75 \leq P / e \leq 1.1$ değiştirilirken, iğne kanatçığın köşe uzunluğu $3 \leq L_{e f} \leq 6$ olarak değiştirilmiştir. Çalışma aralığı türbulanslı akış rejimi olarak düşünülmüştür $(2658 \leq R e \leq 7138)$. Hesaplamalı çalışmada RANS denklemlerini çözmek için low-Re düzeltme modeli ile $S S T k$ - $\omega$ kullanılarak ANSYS Fluent 2020R2 üzerinde gerçekleştirilmiştir. Termo-hidrolik performansı ifade eden ortalama Nusselt sayısı, Ortalama Darcy sürtünme faktörü ve termal rezistans gibi faktörler detaylıca ele alınmıştır. Ayrıca, akış karakteristiğini detaylıca inceleyebilmek için girdap ve sıcaklık eş eğrileri ve hız akış çizgileri oluşturulmuştur. Genel değerlendirme sonucu olarak, Re=7138'de maksimum konvektif ısı transferi performansı Case 1'e kıyasla \%52 oranla Case 12 kullanılarak elde edilmiştir.
\end{abstract}

Anahtar Kelimeler: Isı kuyusu, Altıgen iğne kanatçık, Konvektif ısı transferi, HAD

\footnotetext{
* Corresponding Author: nura561152@gmail.com
} 


\section{Introduction}

After the rapid development of small-sized electrical circuit systems, it has become necessary to manage the thermal technology of high-power devices to suit such development [1]. Keeping electronic devices within the operating temperature range is essential for highly reliable electronic systems. Also, rising temperatures make systems more prone to failure and less reliable. Therefore, it is important to highlight that maintaining electronic systems within the operating temperature not only avoids system failure, but also improves the performance of power electronics components [2]. Thermal energy transfer rates are improved by two types of techniques, passive techniques that do not require additional energy sources, and techniques that require additional energy, and the latter are active technologies [3]. Heat sink, the most common method for passive technique, due to its ability to dissipate large heat in less time in addition to its cheapness and simplicity is one of the most popular heat dissipation techniques in many electronic equipment cooling systems [4], such as computer processor cooling systems, air conditioners and aircraft cooling engines [5]. The heat sink is fitted with fins to increase and improve heat dissipation [6]. A cooling medium is used through the heat sink, and this medium may be air, water or one of the nanofluids [7-13]. One of the most famous techniques used is the forced convection heat sink with air as a cooling medium, and this is needed for ease of maintenance, low cost, and simplicity. Due to the high demand for improving the performance and efficiency of heat dissipation sink [14], it has been taken as a basis for this research work. Comparative studies have been conducted between square and circular configurations of pin fin basins, which showed that circular fins with a diameter of $3 \mathrm{~mm}$ had the best thermal performance in thermal management of electronic devices [15]. The performance is also improved by $30 \%$ in the upstream position of the heat sink $[15,16]$. Then, lateral air performance experiments under mixed convection (natural and forced) for fully covered elliptical fin basins with circular and oval fins [16]. Where the results showed a decrease in thermal performance with increasing the spacing of the fins. Many studies aimed to enhance the efficiency of the heat sink in different ways and techniques summarized by Prabhakar and Prajapati [17]. A study by Bhandari and Prajapati, the effect of fin length has been studied for a small channel containing an open space between the two surfaces, the bottom surface of the heat dissipation basin and the upper surface of the fin. The results showed that the heat transfer rate is enhanced when the fin length reaches $1.5 \mathrm{~mm}$ and tends to decrease after this value [18]. Experiments reported the effect of both forced and natural convection on a heat sink with a flat copper metal base with fins for heat dissipation where the power input has been heated by Ozsipahi et al. [19]. Conducted twentythree three-dimensional simulations, where each design parameter has been examined in three variables, where the fin height, distance between the fins and Reynolds number have been determined as design parameters, while the heat sink resistance and pressure drop are the performance criteria, as the fin height with increasing Reynolds number lead to a decrease in thermal resistance. The numerical investigation has been done by Soleymani et al. [20] to examine the heat transfer rate in a hybrid heat sink consisting of twenty-five fins in the back region and forty-three in the hotspot region, where the geometric properties such as fin shape, angle, microchannel wall wave, and Reynolds number have been investigated. The results showed that the fin with rounded edges has better thermal performance than the other design parameters, and the heat transfer rate increases with the increase in the angle. In addition, as the increase in the height of the wall wave increases the convective heat transfer rate. A new design has been made for a heat sink by Wang et al. [21], which contains double channels that combine porous vertical ribs and wavy micro-channels. The flow behaviour of this design has been examined by applying three different conditions. As it has been found that the thermal resistance decreases with increases porous permeability. Saravanakumar and Kumar [22] worked on performing an experimental investigation to elucidate hydrothermal performance of the heat sink with/without rectangular fins under forced convection in different factors. It is concluded that heat sink with rectangular fins presents higher heat transfer rate than smooth heat sink by $10 \%$. Attar et al. [23] investigated a micro-processor cooling with heat sink. The novel heat sink design has been compared to conventional one. Heat dissipation from heat sink has been monitored atomic force microscopy, and electron microscopy to examine the surface structures of heat sinks. This study aims to demonstrate the possibility of reducing the weight of aluminium heat sinks, the thermal management of a system with a higher heat transfer by using a heat sink of a certain size.

After literature review, it has been found that there is no adequate research showing the effect of changing different heat sink with pin fin parameters, so this research is a stimulating new horizon to literature. Where this research aims to study the thermal and hydraulic performance characteristics of the hexagonal pin fins.

\section{Material and Method}

\subsection{Physical Model}

The model has been constructed with two different parts: a rectangular duct and a heat sink with hexagonal pin fins. The fundamental dimensions of numerical model and the cases is presented in Fig. 1. The cross-section of the rectangular duct has been taken to be 120x120 mm and the length equals to $500 \mathrm{~mm}$. Also, the heat sink has been taken place with 25 pin fins on the square plain with $100 \times 100 \mathrm{~mm}$ placed at the middle of the rectangular duct. In addition, $5 \mathrm{~mm}$ gap has been left between square base of heat sink and bottom surface of rectangular duct. The distance between fin-to-fin toward streamwise direction has been taken constant as $20 \mathrm{~mm}$ and the distance between fin-to-fin toward spanwise direction has been changed with the dimensionless form $(P / e)$. While $P$ defines the spanwise direction with three different values $15 \mathrm{~mm}, 20 \mathrm{~mm}$, and $22 \mathrm{~mm}, e$ explains the streamwise direction as a constant value equal to $20 \mathrm{~mm}$. The edge length of the fins has been taken with different values as 6 $\mathrm{mm}, 5 \mathrm{~mm}, 4 \mathrm{~mm}$, and $3 \mathrm{~mm}$. The schematic view of the fluid domain and the boundary conditions can be seen in Fig. 2. In this study, the turbulent flow condition in the transient region has been performed with $2658 \leq R e \leq 7138$. 


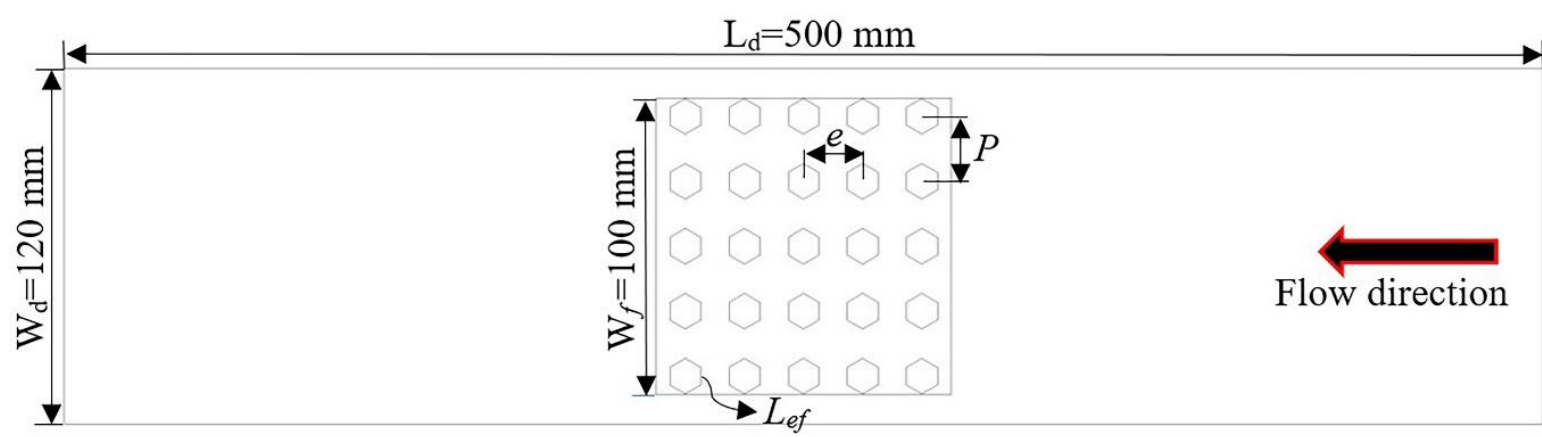

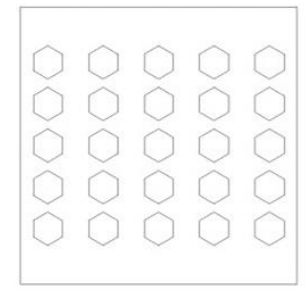

Case $1, P / e=0.75, L_{e f}=6 \mathrm{~mm}$

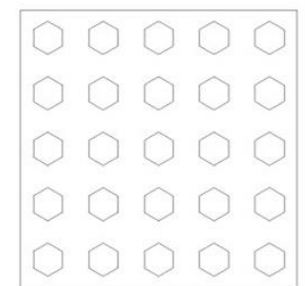

Case 2, $P / e=1.00, L_{e f}=6 \mathrm{~mm}$

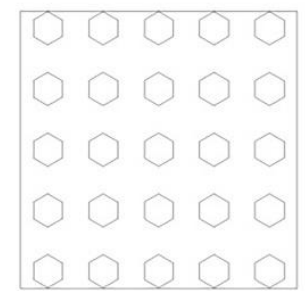

Case $3, P / e=1.10, L_{e f}=6 \mathrm{~mm}$

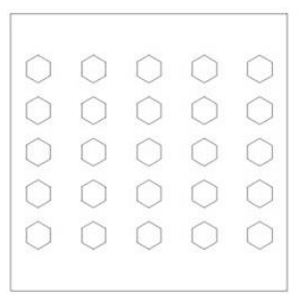

Case $4, P / e=0.75, L_{e f}=5 \mathrm{~mm}$

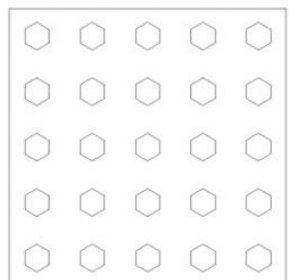

Case $5, P / e=1.00, L_{e f}=5 \mathrm{~mm}$

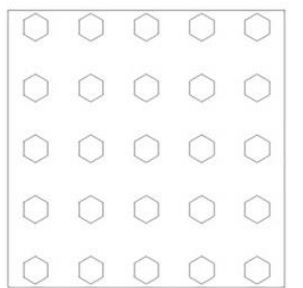

Case 6, $P / e=1.10, L_{e f}=5 \mathrm{~mm}$

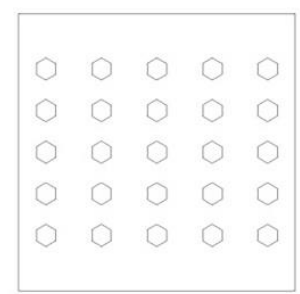

Case 7, $P / e=0.75, L_{e f}=4 \mathrm{~mm}$ Case 10,P/e=0.75, $L_{e f}=3 \mathrm{~mm}$
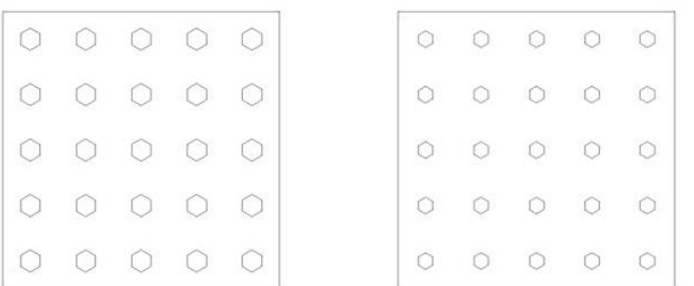

Case 8,P/e=1.00, $L_{e f}=4 \mathrm{~mm}$ Case 11, P/e $=1.00, L_{e f}=3 \mathrm{~mm}$
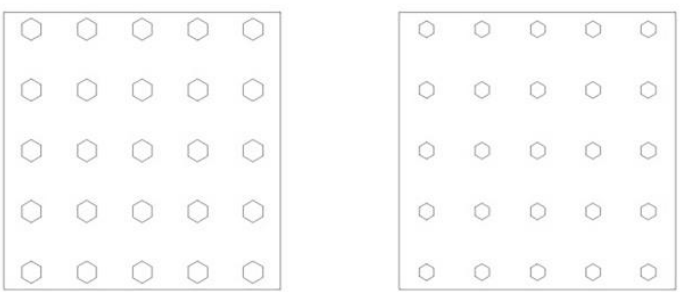

Case 9, $P / e=1.10, L_{e f}=4 \mathrm{~mm}$ Case 12, $P / e=1.10, L_{e f}=3 \mathrm{~mm}$

\subsection{Governing Equations}

All simulations have been carried out using ANSYS Fluent 2020R2 and based on RANS (Reynolds-Averaged Navier-Stokes equations) equations. The physical model has been designed as 3 $D$ model. Also, to solve computational domain, SST $k$ - $\omega$ with low$R e$ correction model has been utilized for all analyses. Enhanced Wall Treatment model has been applied as the wall treatment model. Also, the governing equations used in the analyses are presented as following:

Conservation of mass:

$\frac{\partial \rho}{\partial t}+\frac{\partial\left(\rho u_{i}\right)}{d x}=0$

Conservation of momentum:

$\frac{\partial\left(\rho u_{i}\right)}{\partial t}+\frac{\partial\left(\rho u_{i} u_{j}\right)}{\partial x_{j}}=-\frac{\partial P}{\partial x_{i}}+\frac{\partial}{\partial x_{j}}\left[\mu\left(\frac{\partial u_{i}}{\partial u_{j}}+\frac{\partial u_{j}}{\partial x_{i}}-\frac{2}{3} \delta_{i j} \frac{\partial u_{i}}{\partial x_{j}}\right)\right]+i \frac{\partial}{\partial x_{j}}\left(-\rho \overline{u_{i}^{\prime u_{j}^{\prime}}}\right)$

Conservation of energy:

$\frac{\partial}{\partial t}(\rho E)+\frac{\partial}{\partial x_{i}}\left[u_{i}(\rho E+\operatorname{Pr})\right]=\frac{\partial}{\partial t}\left[\left(k+\frac{C \mu_{i}}{\operatorname{Pr}_{t}}\right)\right] \frac{\partial T}{\partial x_{j}}+\mu_{i}\left(\tau_{i j}\right)_{e f f}$
Turbulence equations:

$\frac{\partial(\rho k)}{\partial t}+\frac{\partial\left(\rho k u_{i}\right)}{\partial x_{i}}=\frac{\partial}{\partial x_{j}}\left(\Gamma_{k} \frac{\partial k}{\partial x_{j}}\right)+G_{k}-Y_{k}+S_{k}$

$\frac{\partial(\rho \omega)}{\partial t}+\frac{\partial\left(\rho \omega u_{i}\right)}{\partial x_{i}}=\frac{\partial}{\partial x_{j}}\left(\Gamma_{\omega} \frac{\partial k}{\partial x_{j}}\right)+G_{\omega}-Y_{\omega}+S_{\omega}$

Also, to express of the results from calculations, nondimensional numbers have been used in this study:

Reynolds number can be defined as:

$R e=\frac{\rho V D_{\mathrm{h}}}{\mu}$

where, $\rho\left[\mathrm{kg} / \mathrm{m}^{3}\right], V[\mathrm{~m} / \mathrm{s}], D_{h}$ and $\mu[\mathrm{kg} / \mathrm{ms}]$ is the density of working fluid at bulk temperature, the average velocity, the hydraulic diameter of the duct, and the dynamic viscosity of working fluid at bulk temperature, respectively. 


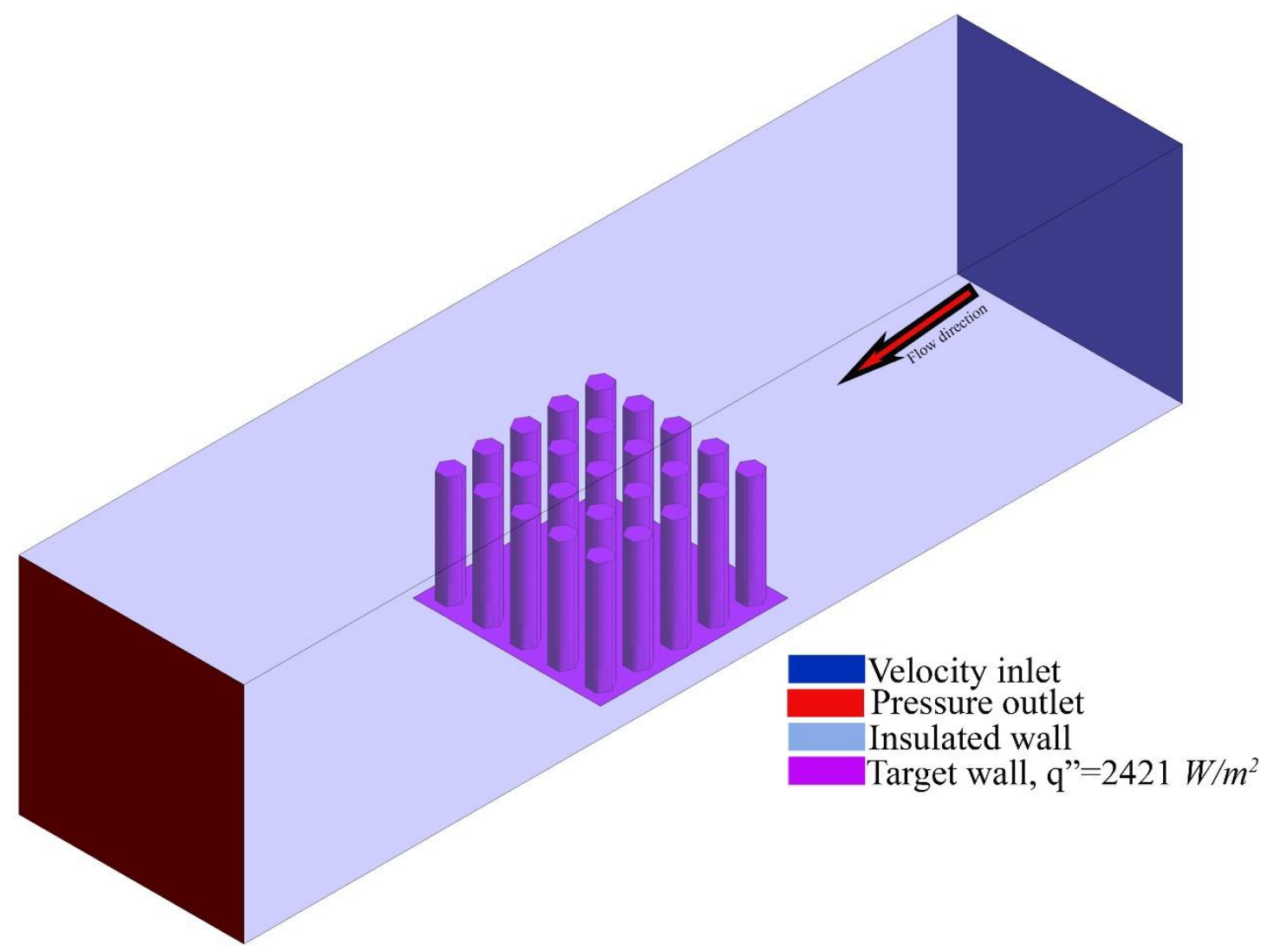

Fig. 2. Explanation of computational domain and the boundary condition.

Convection heat transfer rate can be calculated as:

$$
h=\frac{q^{\prime \prime}}{\left(T_{w}-T_{b}\right)}
$$

where, heat flux is defined as $q^{\prime \prime}\left[W / m^{2}\right] . \quad T_{w} \quad[K]$ is average surface temperature of heat $\operatorname{sink}\left(T_{\text {wall, } H S}\right), T_{b}[K]$ is also average temperature of inlet and outlet temperatures.

Average Nusselt number $(\mathrm{Nu})$ can be defined as:

$$
N u=\frac{h D_{\mathrm{h}}}{k}
$$

where, $k[W / m . K]$ is the thermal conductivity of the working fluid at the bulk temperature.

Thermal resistance $(R)$ can also be calculated as follow:

$R=\frac{T_{a v g ., H S}-T_{i n}}{q^{\prime \prime}}$

The turbulent intensity can be expressed with Eq. (10) as:

$I=0.16 \operatorname{Re}^{(-1 / 8)}$
Average Darcy friction factor $(f)$ can be calculated by using:

$$
f=\frac{\Delta P}{\left(\frac{L}{D}\right) \cdot\left(\frac{\rho \cdot V^{2}}{2}\right)}
$$

where, $\Delta P$ is the pressure drop, $L$ is the total length of duct, $D$ defines hydraulic diameter, $\rho$ is the density of working fluid.

\subsection{Numerical Details}

The fluid is entered at a temperature of $T_{i n}=300 \mathrm{~K}$ into a numerical domain. While the no-slip condition with constant heat flux boundary condition have been conducted to heat sink, the noslip condition with adiabatic boundary condition have been applied on the duct's surfaces. The pressure outlet boundary condition has been applied for outlet section. In terms of more accurate and fast solution for internal flow, the SIMPLE pressurevelocity coupling method has been utilized all of the analyses [24]. Since the aspect ratio is lower than 10 and the orthogonal quality is higher than 1 , the second-order upwind scheme has been used for numerical analyses. The all residuals have been reached $10^{-6}$ as a converging criterion. Also, the boundary conditions are presented in Table 1. Thermo-physical properties of working fluid can also be seen from Table 2 . 
Table 1

\begin{tabular}{lll}
\hline Re & - & $2658-7138$ \\
\hline Average Velocity & $\mathbf{m} / \mathbf{s}$ & $0.35-0.94$ \\
\hline Pressure Outlet & $\boldsymbol{a t m}$ & 1 \\
\hline Turbulence Intensity & $\boldsymbol{\%}$ & $5.21-5.97$ \\
\hline $\boldsymbol{q} ”$ & $\mathbf{W / \mathbf { m } ^ { 2 }}$ & 2421 \\
\hline
\end{tabular}

Table 2

\begin{tabular}{lllll}
\hline Fluid & $\begin{array}{l}\text { Density } \\
{\left[\mathrm{kg} / \mathrm{m}^{3}\right]}\end{array}$ & $\begin{array}{l}\text { Dynamic } \\
\text { Viscosity } \\
{[\text { Pa.s }]}\end{array}$ & $\begin{array}{l}\text { Specific } \\
\text { Heat } \\
{[\mathrm{J} / \mathrm{kgK}]}\end{array}$ & $\begin{array}{l}\text { Thermal } \\
\text { Conductivity } \\
{[\mathrm{W} / \mathrm{mK}]}\end{array}$ \\
\hline Air & 1.176 & $1.858 \mathrm{e}-05$ & 1007 & 0.02566 \\
\hline
\end{tabular}

\subsection{Mesh Verification Study}

The one of the important things needed to be considered is mesh independency study to ensure whether analysis results change with variation of mesh number or not. To determine feasible mesh number, numerical calculations with the eight different mesh numbers have been performed. The all mesh studies have been performed for Case 2 at $R e=7138$. As can be seen from the Fig. 3, there is not any considerable changing after sixth mesh structure for average Nusselt number and average Darcy friction factor. Therefore, the sixth mesh structure (Mesh Elements Number $=1194130$ ) has been chosen for the optimum mesh structure for this study. As can be seen from Fig. 4, the denser mesh has been applied for inlet, outlet of the duct and onto

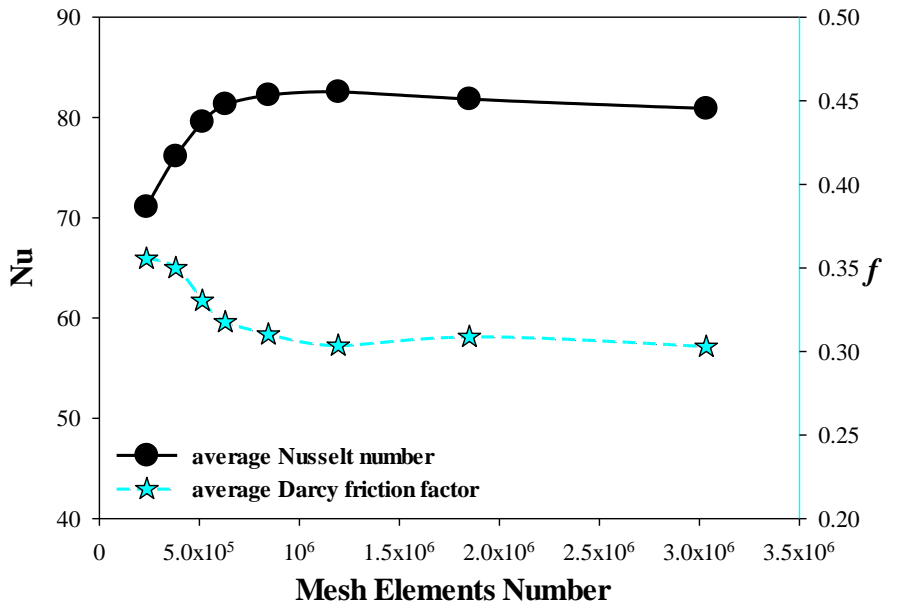

Fig. 3. Mesh independence study at $R e=7138$.

the heat sink placed at the middle of the duct. Also, the aspect ratio, orthogonal quality and skewness values, which define the quality of the mesh structure, have been monitored for each analysis to examine mesh quality. It is noted that there is another criterion determining analysis quality norm is normalized distance from the wall $\left(y^{+}\right)$. When the SST k- $\omega$ with low-Re correction model is used, the $y^{+}$value should be lower than 1 to obtain feasible calculation near the walls. For this prupose, the $\mathrm{y}^{+}$ value has been kept almost 0.3845 for each case.

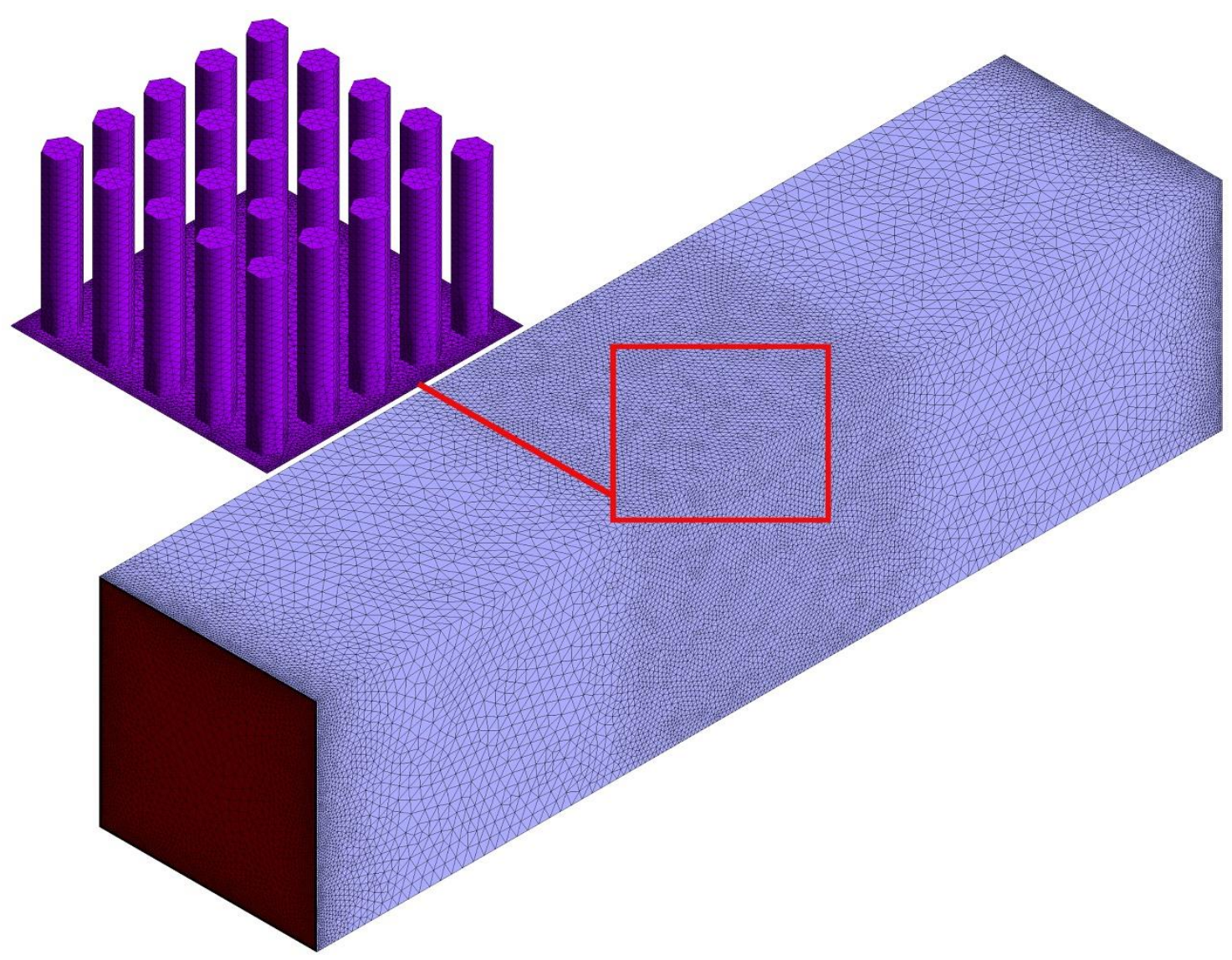

Fig. 4. Mesh structure of computational domain. 


\subsection{Selection of Turbulence Model and Validation with Literature}

To perform a study under turbulent flow condition, there are several types of turbulence models in the ANSYS Fluent. Hence, the calculation performance of different turbulence models should be obtained for the same case to determine optimum feasible turbulence model. In this study, SST k- $\omega$, Transition SST, RNG k$\varepsilon$, Realizable $k-\varepsilon$ turbulence models have been calculated to compare with the experimental data of El-Said et al [1]. As can be seen from Fig. 5, the average Nusselt number and average Darcy friction factor variation with the Reynolds number are shown for different turbulence models. It is concluded that the $R N G k-\varepsilon$, and Realizable $k-\varepsilon$ turbulence models have been presented overestimated deviation in comparison with experimental data by $9 \%$ and $10.72 \%$, respectively. Nonetheless, while the Transition SST shows the deviation almost $6 \%$, the $S S T k-\omega$, which presents the most feasible result, establishes the deviation almost $4 \%$ in comparison with experimental data of El-Said et al. [1].

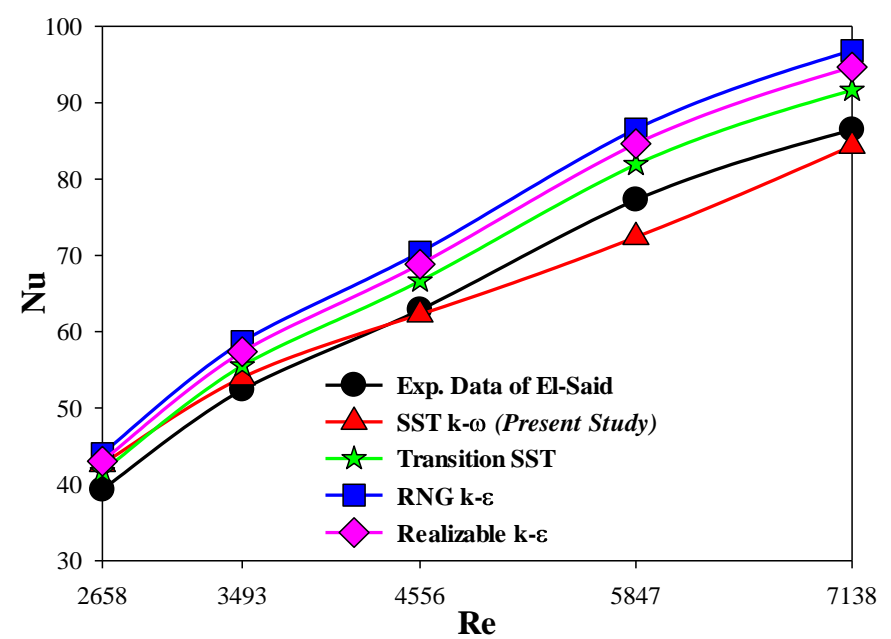

a)

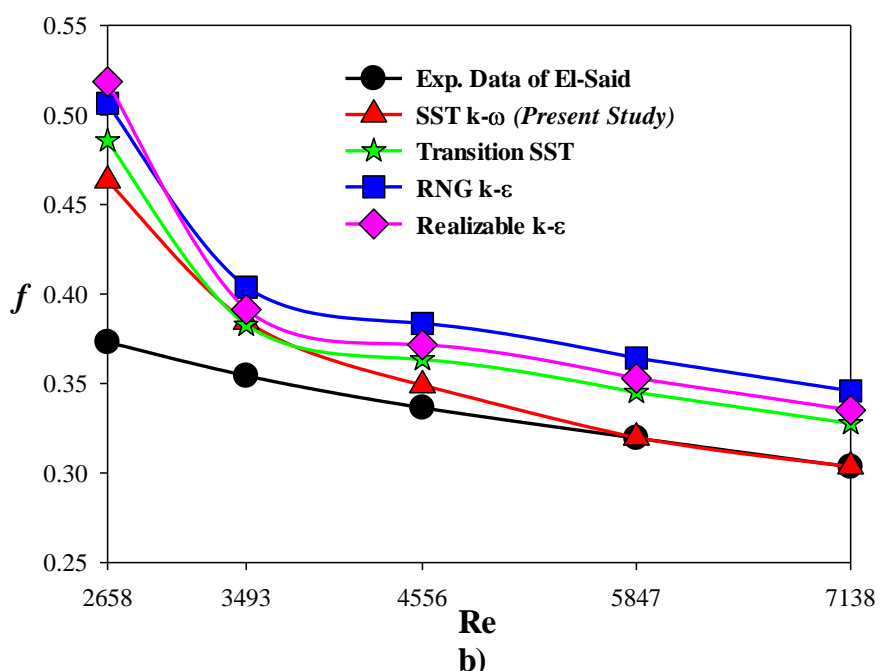

Fig. 5. Performance comparison of different turbulence model for a) average Nusselt number, b) average Darcy friction factor.

\section{Results and Discussion}

\subsection{Effect of pitch ratio and diagonal length of pin fin on convective heat transfer and temperature distribution}

The impact of different cases in terms of the average Nusselt number distribution with Reynolds number can be seen in Fig. 6 . As can be expected, the minimum and maximum value for average Nusselt numbers have been obtained in minimum and maximum Reynolds numbers, respectively. In addition, the highest convective heat transfer rate obtains in Case 12 and the lowest one with Case 1 in all Reynolds numbers. While the Case 12 presents enhancement in heat transfer rate by $56 \%$ at $R e=2658$ in comparison with Case 1, it provides increment by $52 \%$ at $R e=7138$. It is concluded that the increment pitch ratio and decrease diagonal length provide more heat transfer.

Also, the surface Nusselt number distribution can be seen in Fig. 7 for $R e=7138$. The surface Nusselt number enhances by increasing the pitch ratio and decreasing diagonal length of pin fin due to providing more stable fluid flow over the heat sink. Also, the surface Nusselt number decreases toward streamwise direction but the decrease in surface Nusselt number can be minimized by increasing the pitch ratio and decreasing diagonal length of pin fin.

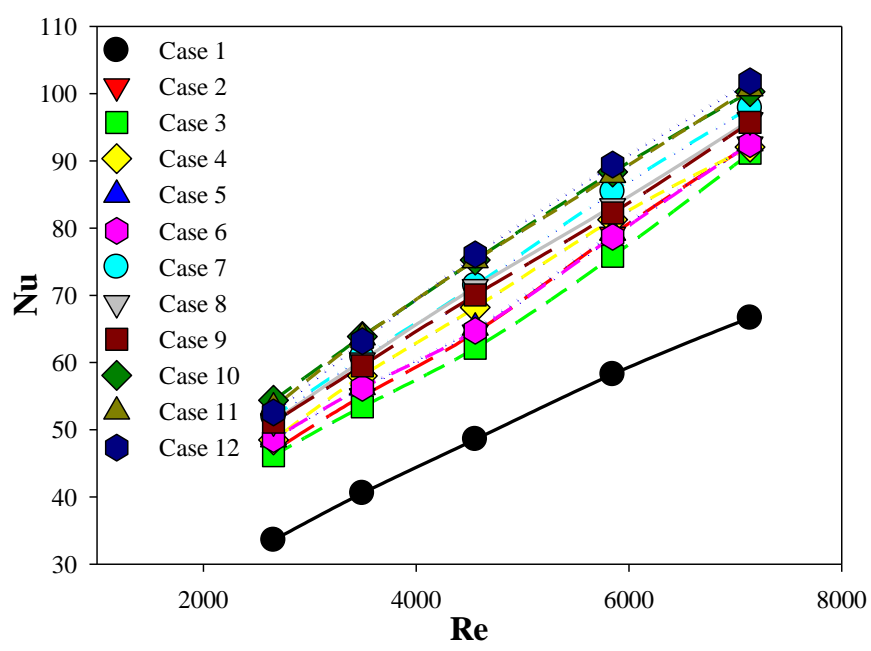

Fig. 6. Variation of average Nusselt number with Reynolds number for different cases.

On the other hand, the hydraulic performance of novel heat sink design is one of the important points to decide if the configuration acceptable or not. Beside of it is importance in determining configuration, it is also important in terms of research, innovation, and commercialization. For this purpose, variation of average Darcy friction factor is given in Fig. 8 to elucidate hydraulic performance of heat sink. While the maximum average Darcy friction factor has been obtained at $R e=2658$, the minimum one acquired at $R e=7138$. Then, the optimum enhancement in average Darcy friction factor is obtained in Case 12 for all Reynolds numbers in comparison with other cases. While it is obtained as 0.43 in Case 1 at $R e=7138$, it is acquired as 0.21 in Case 12 at $R e=7138$. 


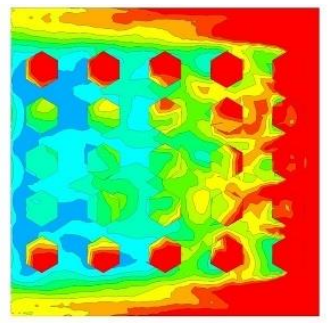

Case 1

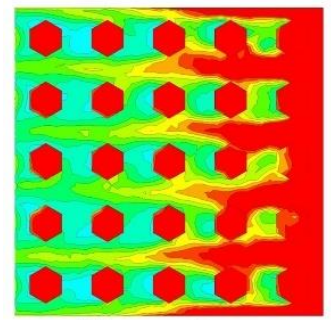

Case 2

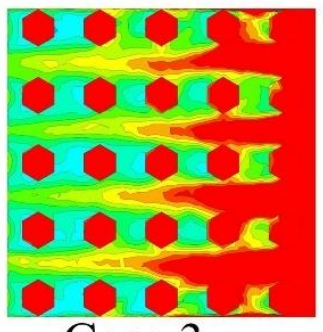

Case 3

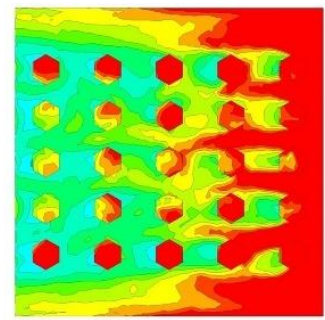

Case 4

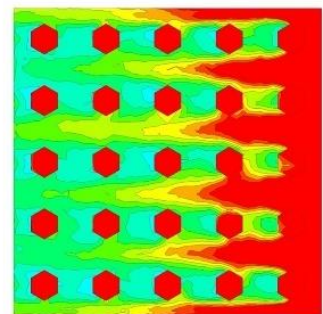

Case 5

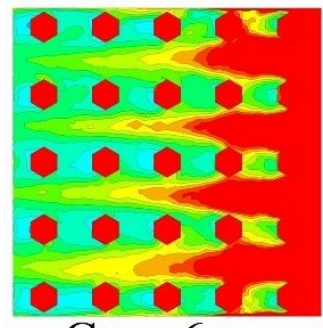

Case 6

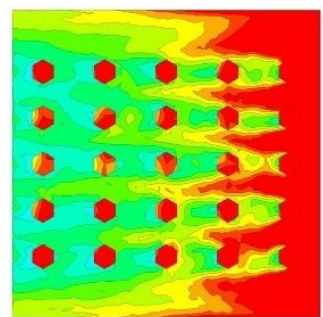

Case 7

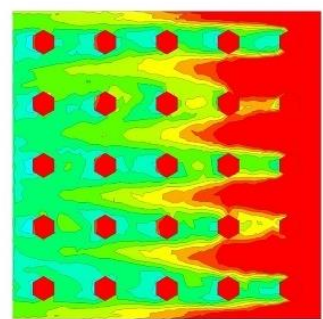

Case 8

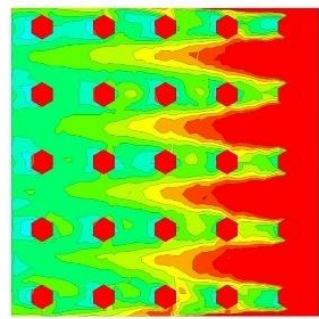

Case 9

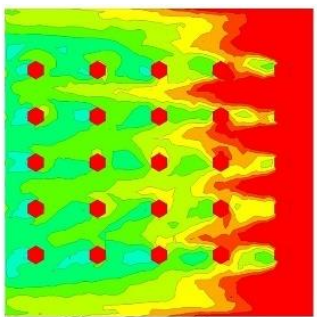

Case 10

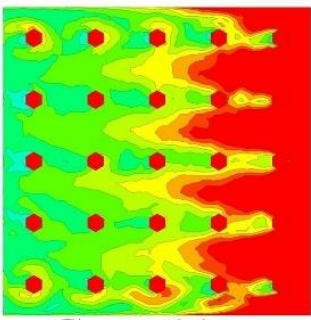

Case 11

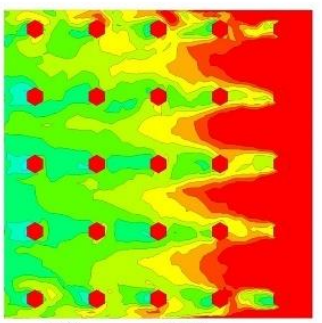

Case 12

Fig. 7. Surface Nusslet number distribution over the heat sink for different cases at $R e=7138$.

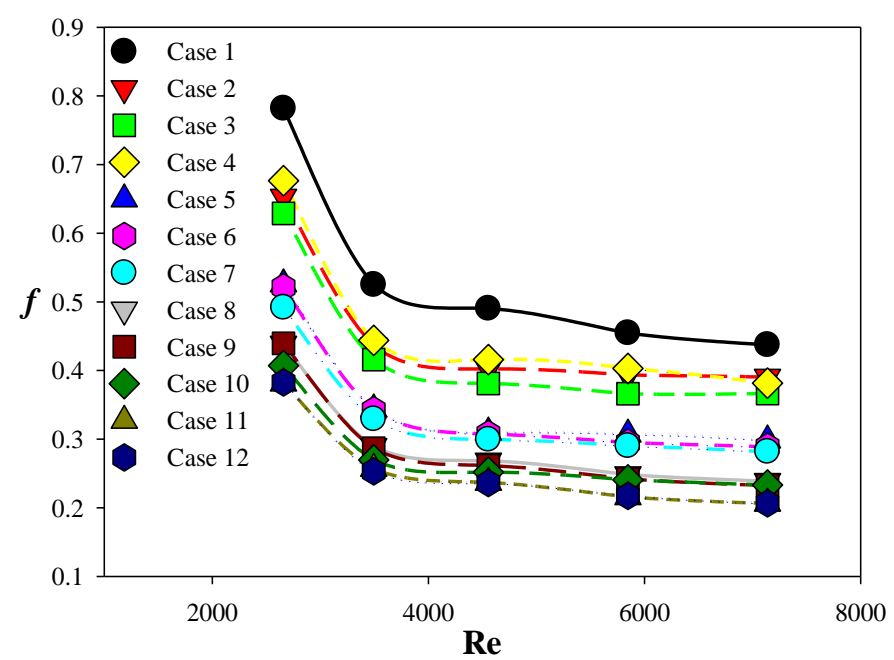

Fig. 8. Variation of average Darcy friction factor with Reynolds number for different cases.

The surface temperature contours are seen in Fig. 9 for all cases at $R e=7138$. As can be seen that the comparatively low temperature region is taken place at the first interaction region between fluid and heat sink toward the streamwise, but the effectivity of coolant fluid is decreased toward the streamwise due to more interaction between fluid and heat sink. Also, the minimum effective cooling over heat sink is achieved in Case 1 and the maximum effective cooling over heat sink is obtained in Case 12 .

Also, the wider diagonal length leads to less cooling over the heat sink, but the narrower diagonal length leads to more cooling over the heat sink for all cases due to increment in interaction coolant fluid and heat sink. That is why the more convective heat transfer rate is obtained in Case 12 for all Reynolds numbers. Variation of average surface temperature of heat sink with all Reynolds numbers is presented in Fig. 10. As can be seen in this figure, while the minimum cooling of heat sink is achieved in Case 1, the maximum cooling performance is obtained in Case 12 for all Reynolds numbers. Then, the maximum average heat sink surface temperature is achieved at minimum Reynolds number, the minimum average surface temperature of heat sink is also seen at maximum Reynolds number. Although the lower diagonal length and wider pitch ratio of pin fins for Case 12, average temperature of heat sink is lower compared with other cases. That is why the utilizing small diagonal length with high pitch ratio leads to passing faster flow among the pin fins and heat sink surface and the lower average surface temperature and higher heat transfer rate is achieved for all Reynolds numbers.

The thermal resistance, which is important parameter for heat sink, can be seen for all cases versus Reynolds number in Fig. 11. While the higher thermal resistance is obtained with Case 1, the lower one with Case 12 due to comparatively lower average surface temperature of heat sink. This trend is the same with Fig. 10. 


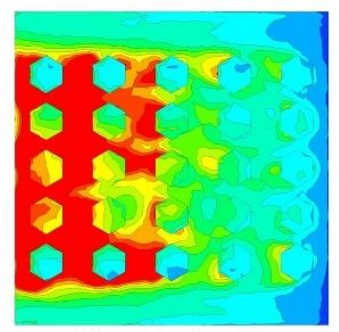

Case 1

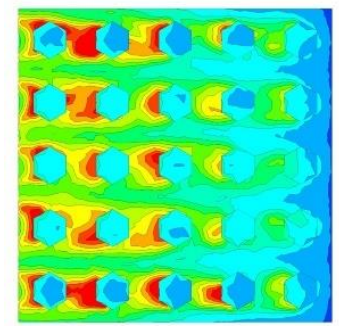

Case 2

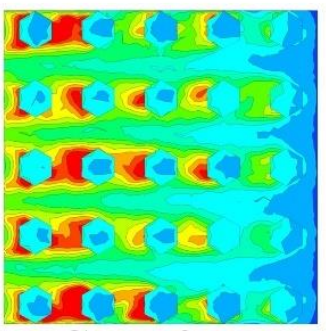

Case 3

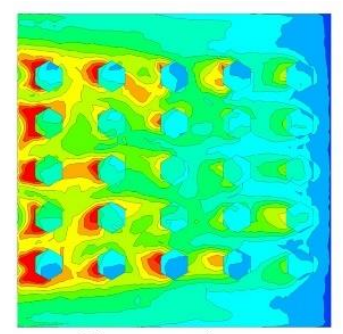

Case 4

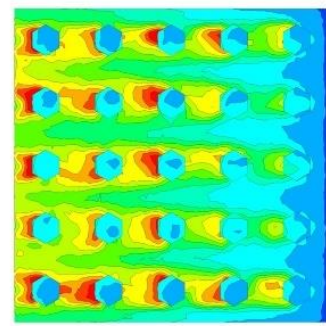

Case 5

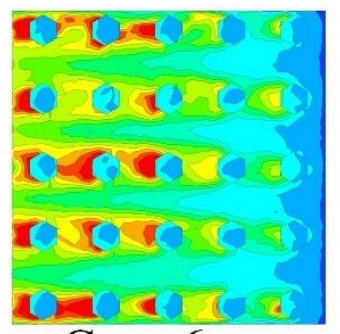

Case 6

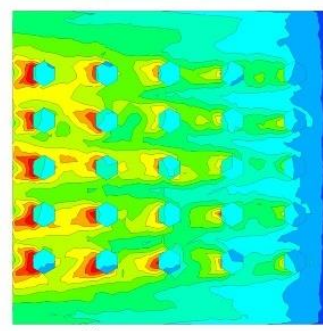

Case 7

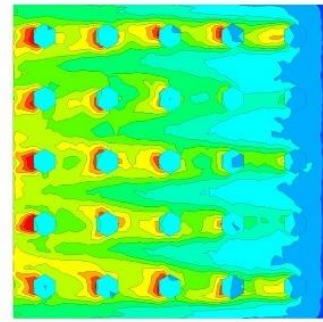

Case 8

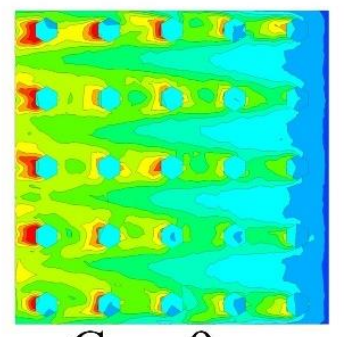

Case 9

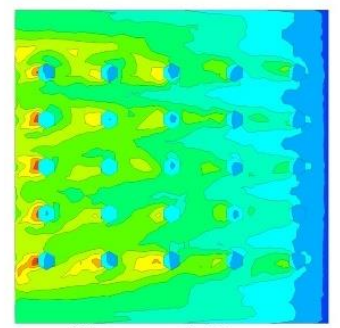

Case 10

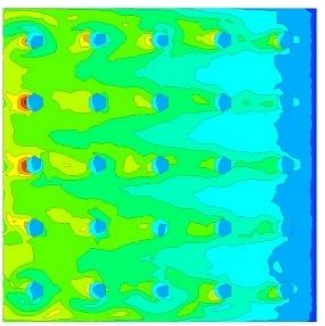

Case 11

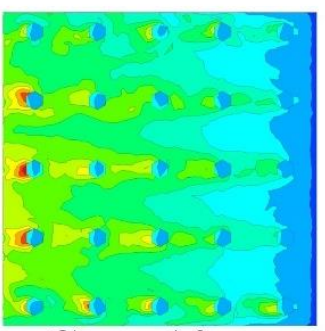

Case 12

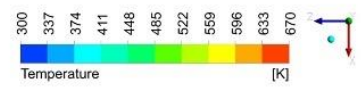

Fig. 9. Heat sink surface temperature distribution in different cases at $R e=7138$.

Also, it is noted that increase in Reynolds number leads to decrease in thermal resistance, which is associated with increment in thermal performance of heat sink. Also, decrease in thermal resistance can be associated with more uniform mixing coolant fluid flow inside the heat sink, which means automatically effect convective heat transfer performance positively.

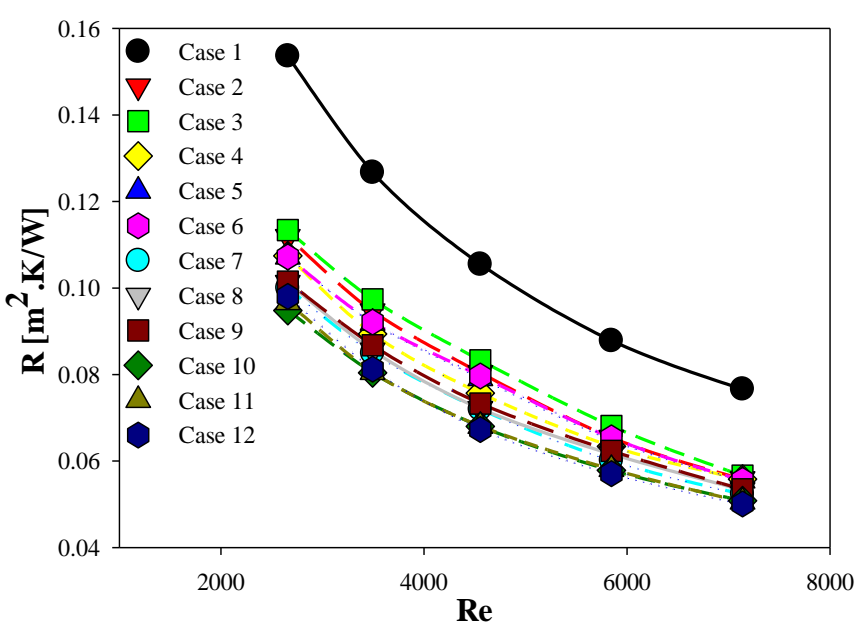

Fig. 11. Variation of thermal resistance with Reynolds number for all cases.

\subsection{Assesment of flow characretistics}

Fig. 12 establishes the vorticity contours over heat sink for all cases at $R e=7138$. As can be seen from this figure, strong vorticities are occurred top and bottom surface on $\mathrm{X}$ direction and at the beginning of the heat sink on $\mathrm{Z}$ direction and first column of pin fins due to more higher fluid velocity.

Also, it should be realized that an increase the pitch ratio and a decrease diagonal length of pin fins cause decrease in vorticity occurring due to more uniformly distribution for fluid flow among pin fins. The vorticities are taken place higher with increase pitch ratio on the bottom surface of heat sink and occurred less with the decrease diagonal length on the top surface of pin fin. The occurrence of more uniform and stronger vorticity over the heat sink by increasing pitch ratio and decreasing diagonal length leads to enhancement convective heat transfer rate.

Fig. 13 shows velocity streamlines for all cases at $R e=7138$. As can be seen clearly from this figure, the coolant velocity is relatively higher at the beginning of the heat sink for Case 1 and Case 4, but it decreases as the moving fluid toward the streamwise direction due to denser configuration of pin fins. Nevertheless, with the increase in pitch ratio and decrease in diagonal length, the more uniform streamline can be achieved over heat sink. With the help of uniform fluid flow, uniform surface temperature distribution can be achieved over heat sink and so the higher convective heat transfer rate also can be obtained. 


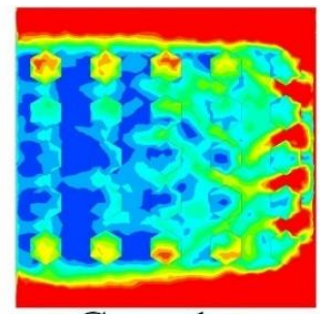

Case 1

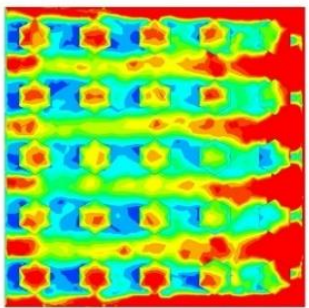

Case 2

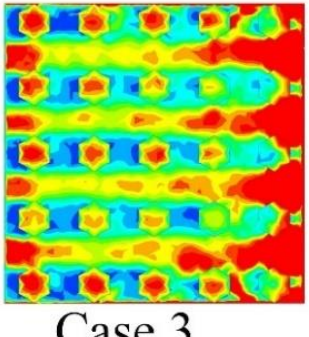

Case 3

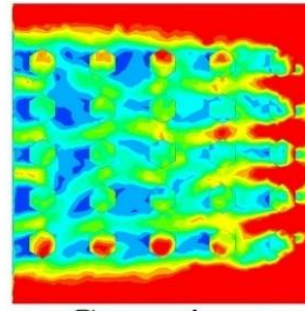

Case 4

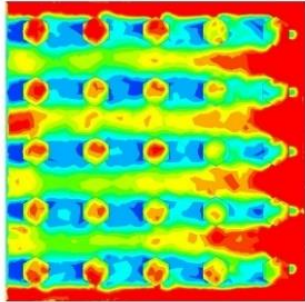

Case 5

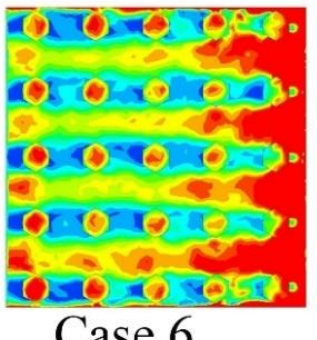

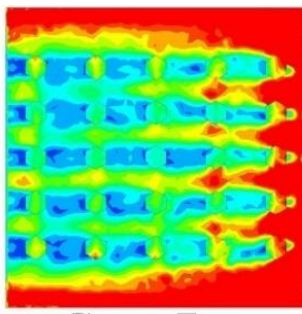

Case 7

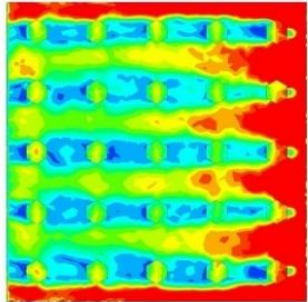

Case 8

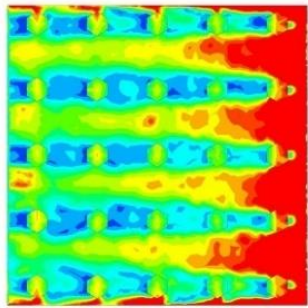

Case 9

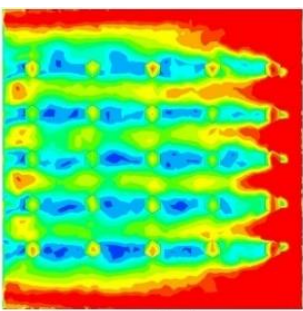

Case 10

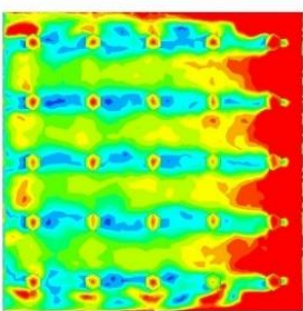

Case 11

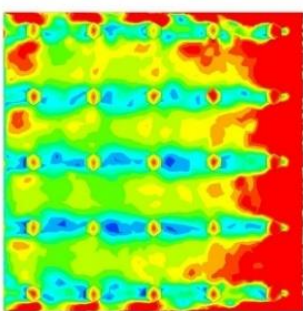

Case 12

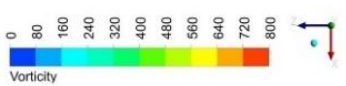

Fig. 12. Vorticity variations over the heat sink in different cases at $R e=7138$.

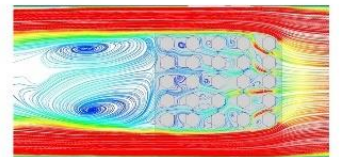

Case 1
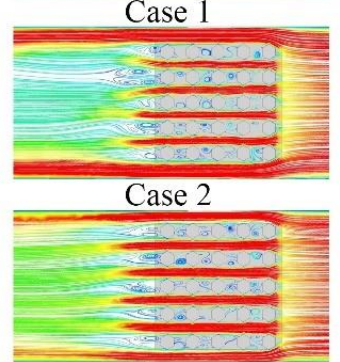

Case 3

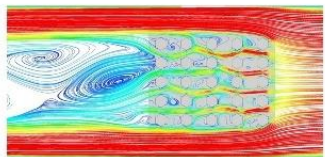

Case 4

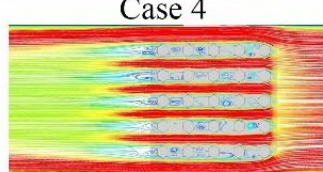

Case 5

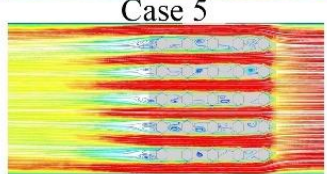

Case 6

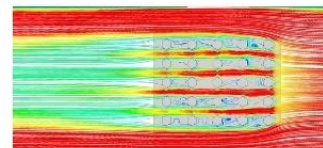

Case 7

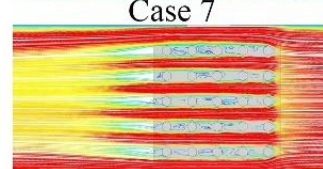

Case 8

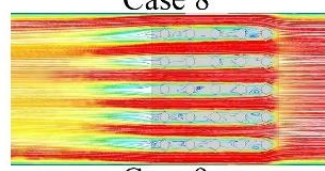

Case 9

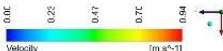

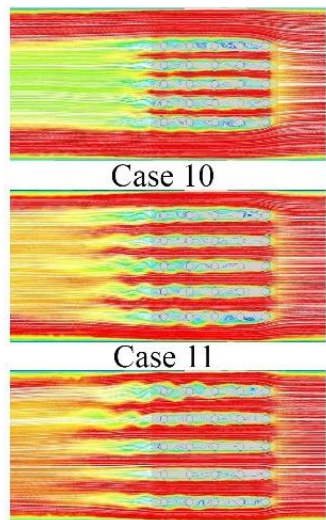

Case 12

Fig. 13. Velocity streamlines toward streamwise direction for all cases at $R e=7138$.

\section{Conclusions and Recommendations}

In the present study, the numerical computations are performed to elucidate thermo-hydraulic performance of different configurations of heat sink with pin fins under turbulent flow conditions. The impact of Reynolds number, pitch ratio and diagonal length of pin fins are studied.

The findings are described as follows:

- An increment in Reynolds number and pitch ratio enhances the convective heat transfer rate, decreases average surface temperature of the heat sink. Besides, a decrease in diagonal length provides an increment in e-ISSN: 2148-2683 convection coefficient and more uniform surface temperature distribution.

- While the Case 1 gives the lowest convective heat transfer rate, the Case 12 presents the highest convective heat transfer rate for all Reynolds numbers.

- The enhancement of Average Nusselt number for Case 12 is obtained by $56.52 \%, 55.75 \%, 56.68 \%, 53.62 \%$, and $52.77 \%$ for $R e=2658,3493,4556,5847$, and 7138 compared with Case 1, respectively.

- The enhancement of average Darcy friction factor for Case 12 is acquired with $104.35 \%, 107.48 \%, 107.68 \%$, 
$109.05 \%$, and $111.87 \% \operatorname{Re}=2658,3493,4556,5847$, and 7138 compared with Case 1 , respectively.

- Consequently, the overall assessment of this study is that higher pitch ratio with lower diagonal length provides higher convective heat transfer rate due to uniform fluid moving among the pin fins.

\section{References}

[1] E.M.S. El-Said, G.B. Abdelaziz, S.W. Sharshir, A.H. Elsheikh, A.M. Elsaid, Experimental investigation of the twist angle effects on thermo-hydraulic performance of a square and hexagonal pin fin array in forced convection, Int. Commun. Heat Mass Transf. $126 \quad$ (2021) 105374. https://doi.org/10.1016/J.ICHEATMASSTRANSFER.2021. 105374.

[2] B. Sahin, K. Yakut, I. Kotcioglu, C. Celik, Optimum design parameters of a heat exchanger, Appl. Energy. 82 (2005) 90 106. https://doi.org/10.1016/J.APENERGY.2004.10.002.

[3] Y.F. Pang, Assessment of Thermal Behavior and Development of Thermal Design Guidelines for Integrated Power Electronics Modules, (2005).

[4] N.A.C. Sidik, M.N.A.W. Muhamad, W.M.A.A. Japar, Z.A. Rasid, An overview of passive techniques for heat transfer augmentation in microchannel heat sink, Int. Commun. Heat $\begin{array}{llll}\text { Mass } & \text { Transf. } & 88 & \text { (2017) 74-83. }\end{array}$ https://doi.org/10.1016/J.ICHEATMASSTRANSFER.2017. 08.009 .

[5] M. Turkyilmazoglu, Effective computation of solutions for nonlinear heat transfer problems in Fins, J. Heat Transfer. 136 (2014) 1-6. https://doi.org/10.1115/1.4027772.

[6] M. Turkyilmazoglu, Efficiency of heat and mass transfer in fully wet porous fins: Exponential fins versus straight fins, Int. J. Refrig. $46 \quad$ (2014) 158-164. https://doi.org/10.1016/J.IJREFRIG.2014.04.011.

[7] L. Lin, J. Zhao, G. Lu, X.D. Wang, W.M. Yan, Heat transfer enhancement in microchannel heat sink by wavy channel with changing wavelength/amplitude, Int. J. Therm. Sci. 118 (2017)

$423-434$. https://doi.org/10.1016/J.IJTHERMALSCI.2017.05.013.

[8] N. Patel, H.B. Mehta, Experimental investigations on a variable channel width double layered minichannel heat sink, Int. J. Heat Mass Transf. 165 (2021) 120633. https://doi.org/10.1016/J.IJHEATMASSTRANSFER.2020.1 20633.

[9] H. Mousavi, A.A. Rabienataj Darzi, M. Farhadi, M. Omidi, A novel heat sink design with interrupted, staggered and capped fins, Int. J. Therm. Sci. 127 (2018) 312-320. https://doi.org/10.1016/J.IJTHERMALSCI.2018.02.003.

[10]Y. Yan, Z. He, G. Wu, L. Zhang, Z. Yang, L. Li, Influence of hydrogels embedding positions on automatic adaptive cooling of hot spot in fractal microchannel heat sink, Int. J. $\begin{array}{lllll}\text { Therm. } & \text { Sci. } & 155 & \text { (2020) } & 106428 .\end{array}$ https://doi.org/10.1016/J.IJTHERMALSCI.2020.106428.

[11]M. Izadi, Effects of porous material on transient natural convection heat transfer of nano-fluids inside a triangular chamber, Chinese J. Chem. Eng. 28 (2020) 1203-1213. https://doi.org/10.1016/J.CJCHE.2020.01.021.

[12]M. Izadi, M.A. Sheremet, S.A.M. Mehryan, I. Pop, H.F. Öztop, N. Abu-Hamdeh, MHD thermogravitational convection and thermal radiation of a micropolar nanoliquid in a porous chamber, Int. Commun. Heat Mass Transf. 110 (2020)

104409.
https://doi.org/10.1016/J.ICHEATMASSTRANSFER.2019. 104409.

[13]M. Izadi, M. Javanahram, S.M.H. Zadeh, D. Jing, Hydrodynamic and heat transfer properties of magnetic fluid in porous medium considering nanoparticle shapes and magnetic field-dependent viscosity, Chinese J. Chem. Eng. 28 (2020)

329-339. https://doi.org/10.1016/J.CJCHE.2019.04.024

[14]Y. Yoon, S.J. Park, D.R. Kim, K.S. Lee, Thermal performance improvement based on the partial heating position of a heat sink, Int. J. Heat Mass Transf. 124 (2018) 752-760. https://doi.org/10.1016/J.IJHEATMASSTRANSFER.2018.0 3.080 .

[15]H.M. Ali, A. Arshad, M. Jabbal, P.G. Verdin, Thermal management of electronics devices with PCMs filled pin-fin heat sinks: A comparison, Int. J. Heat Mass Transf. 117 (2018) 1199-1204.

https://doi.org/10.1016/J.IJHEATMASSTRANSFER.2017.1 0.065 .

[16]P.A. Deshmukh, R.M. Warkhedkar, Thermal performance of elliptical pin fin heat sink under combined natural and forced convection, Exp. Therm. Fluid Sci. 50 (2013) 61-68. https://doi.org/10.1016/J.EXPTHERMFLUSCI.2013.05.005

[17]P. Bhandari, Y.K. Prajapati, Thermal performance of open microchannel heat sink with variable pin fin height, Int. J. $\begin{array}{lllll}\text { Therm. } & \text { Sci. } & 159 & \text { (2021) } & 106609 .\end{array}$ https://doi.org/10.1016/J.IJTHERMALSCI.2020.106609.

[18]K.S. Ong, C.F. Tan, K.C. Lai, K.H. Tan, Heat spreading and heat transfer coefficient with fin heat sink, Appl. Therm. Eng. 112 (2017) 1638-1647. https://doi.org/10.1016/J.APPLTHERMALENG.2016.09.16 1.

[19]M. Ozsipahi, A. Subasi, H. Gunes, B. Sahin, Numerical investigation of hydraulic and thermal performance of a honeycomb heat sink, Int. J. Therm. Sci. 134 (2018) 500-506. https://doi.org/10.1016/J.IJTHERMALSCI.2018.07.034.

[20]Z. Soleymani, M. Rahimi, M. Gorzin, Y. Pahamli, Performance analysis of hotspot using geometrical and operational parameters of a microchannel pin-fin hybrid heat sink, Int. J. Heat Mass Transf. 159 (2020) 120141. https://doi.org/10.1016/J.IJHEATMASSTRANSFER.2020.1 20141.

[21]S.-L. Wang, L.-Y. Chen, B.-X. Zhang, Y.-R. Yang, X.-D. Wang, A new design of double-layered microchannel heat sinks with wavy microchannels and porous-ribs, J. Therm. Anal. Calorim. $141 \quad$ (2020) 547-558. https://doi.org/10.1007/s10973-020-09317-3.

[22]T. Saravanakumar, S.D. Kumar, Heat transfer study on different surface textured pin fin heat sink, Int. Commun. HEAT MASS Transf. 119 (2020).

[23]M.R. Attar, M. Mohammadi, A. Taheri, S. Hosseinpour, M. Passandideh-Fard, M. Haddad Sabzevar, A. Davoodi, Heat transfer enhancement of conventional aluminum heat sinks with an innovative, cost-effective, and simple chemical roughening method, Therm. Sci. Eng. Prog. 20 (2020) 100742. https://doi.org/10.1016/J.TSEP.2020.100742.

[24]H.K. Pazarlıoğlu, R. Ekiciler, K. Arslan, Numerical Analysis of Effect of Impinging Jet on Cooling of Solar Air Heater with Longitudinal Fins, Heat Transf. Res. 52 (2021). https://doi.org/10.1615/heattransres.2021037251. 